Article

\title{
The Influence of Apple Orchard Management on Energy Performance and Pruned Biomass Harvesting for Energetic Applications
}

\author{
Arkadiusz Dyjakon $(1)$ \\ Institute of Agricultural Engineering, Wroclaw University of Environmental and Life Sciences, 51-630 Wroclaw, \\ Poland; arkadiusz.dyjakon@upwr.edu.pl; Tel.: +48-71-320-5945
}

Received: 9 December 2018; Accepted: 13 February 2019; Published: 16 February 2019

\begin{abstract}
A further increase of biomass share in energy production in the European Union (EU) causes an interest in new sources of this renewable fuel. Agricultural residues coming from permanent crops, such as apple orchards, can support local actions to combat climate change. However, the amount of pruned biomass possible to be harvested from apple orchards and, thus, the energy output, depend mainly on their proper preparation and management. The managing actions are important because they influence the energy balance, the productivity, and the economy of the harvesting process and the potential benefits from the biomass marketing. In this study, two different variants of pruning management in an apple orchard during biomass harvesting applying baling technology were analyzed. The first variant considered the biomass collection in the orchard with scattered prunings. In the second one, the prunings were windrowed in the middle of the inter-rows. The theoretical potential amounted to $2.5 \mathrm{t}$ (fresh mass) $\mathrm{FM} \cdot \mathrm{ha}^{-1}$. In the case of scattered pruning in the orchard, the harvesting losses were $69.3 \%$ and the energy balance was only $0.76 \mathrm{GJ} \cdot \mathrm{ha}^{-1}$. It resulted in a low biomass yield and a negative economic balance. In turn, for the orchard with windrowed pruning, the harvesting losses were $19.1 \%$ and the energy balance was $20.74 \mathrm{GJ} \cdot \mathrm{ha}^{-1}$. Assuming a biomass price of $€ 90 \mathrm{t}^{-1}$ dry mass (DM), the net benefit excluding transportation of pruned bales was $€ 32.1 \mathrm{ha}^{-1}$. Other calculated energetic factors, such as energy input share, energy return on the investment, productivity, and pruning intensity, confirmed additionally that proper management of the apple orchard increases its energetic potential to be used in the local market. Baling technology can be also competitive with mulching and chipping processes if a market analysis is carried out and the pruned bale sales are guaranteed.
\end{abstract}

Keywords: pruning; agricultural residues; biomass harvesting; bales; energy; production cost

\section{Introduction}

Currently, climate change is the most significant driver influencing the decisions in terms of energy acquisition and its efficient use. From that perspective, an important solution is a replacement of fossil fuels with renewables and improved energy efficiency in production processes [1]. Amongst renewables, biomass is of special interest as it comes from many activities in agriculture and forestry. Therefore, biomass is expected to be a major contributor to the renewable energy targets [2]. Agriculture is an important part of the economy in most countries. It delivers not only food to the market but also energy resources in different forms, including final products, substrates, by-products, and waste. In the world, in addition to crops themselves, large quantities of residues are generated every year, amounting to about 140 billion tons [3]. In 2012, the total supply of biomass in the world amounted to 56.2 EJ; out of this, only 5.6 EJ was associated with the dedicated crops (3.5 EJ) or by-products (2.1 EJ) [4]. For the future, however, the share of agricultural residues is predicted to grow significantly [5]. The average 
global energy yield from the agricultural sector is projected at 64 EJ per year (in 2035) [4], and most of this potential should be available at a relatively low costs in the range \$5-10 per GJ [6] Moreover, from an environmental, economic, and social point of view, biomass acquisition should be in line with a circular bioeconomy which encompasses the production of renewable biological resources and the conversion of these resources and waste streams into value-added products, such as bio-based products and bioenergy [7], as well as the limitation of waste generation [8].

Agricultural residues include all the organic materials which are produced as by-products from agriculture activities. These residues constitute a major part of the total annual production of biomass and are an important source of energy both for domestic and industrial purposes. Agricultural residues can be divided into field-based residues and process-based residues (Table 1). The biomass materials which are generated in the field are defined as field-based residues (e.g., straw). Residues generated during processing of agricultural products are called process-based residues (e.g., maize cob/husk) [9].

Table 1. Examples of frequently available crops and residues.

\begin{tabular}{ccc}
\hline Crop & Category & Residue \\
\hline \multirow{2}{*}{ Wheat } & Field-based & Straw \\
& Process-based & Husk \\
Rape & Field-based & Straw \\
& Process-based & Rapeseed cake \\
Maize & Field-based & Straw \\
& Process-based & Cobs \\
Tea & Field-based & Prune branches \\
& Process-based & Refuse tea \\
Coffee & Field-based & Prune branches \\
& Process-based & Refuse coffee \\
Vegetables & Field-based & Leaves \\
& Process-based & Spoiled vegetables \\
Animals & Field-based & Manure \\
& Process-based & Wastewater \\
Apple & Field-based & Prune branches/leaves \\
& Process-based & Spoiled apples/pomace \\
Cherry & Field-based & Prune branches/leaves \\
& Process-based & Spoiled cherries/seeds \\
Vineyard & Field-based & Prune branches/leaves \\
& Process-based & Spoiled fruit/pomace \\
\hline
\end{tabular}

Such classification is important, especially under the context of energy application, as the availability and accessibility of these sources critically depend on this attribute. The process-based residues are usually available in a relatively high concentration and may be used as an energy source for the same industry contributing to no or little transportation and handling costs. The availability of field-based residues for energy application is very often seasonal and might be limited, since collection for utilization is difficult and there are other alternative uses such as soil improvement and animal feed.

One of the field-based agricultural residues involves cut branches from regular permanent tree crop pruning, such as vineyards, olives, apples, etc. [10-12]. Amongst permanent fruit crops in Poland, apple orchards cover the largest area, resulting in theoretical energy potential of 9.3 PJ per year [13]. Although these agricultural residues might be used as fuel, large amounts are wasted via open dumping or open burning in the field and, therefore, are referred to as waste agricultural biomass [14]. As such, use of these materials for energy applications would be an effective way of managing the waste, while becoming a useful resource rather than a waste material under conventional management practices (Figure 1). 


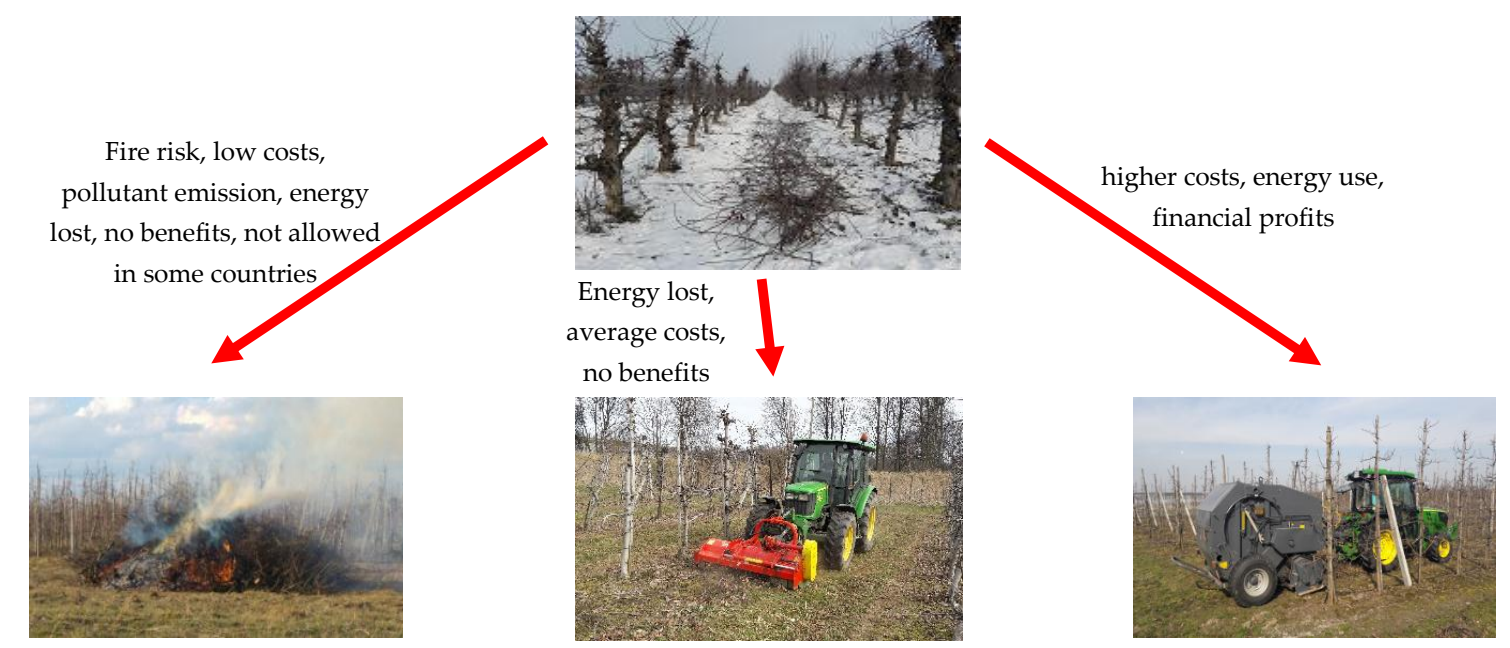

Figure 1. Management options in an apple orchard.

Apple production and related activities in the orchards requires the use of energy in the form of industrial inputs such as fuel and machinery. Energy is one of the most important factors for sustainability evaluation of agricultural production systems [15]. Today, a considerable portion of energy is used to mechanize agricultural operations, and the additional costs are spent to provide the required power on agricultural mechanization.

Energy flow analysis in apple orchards allows determining the energy consumption in relation to the inputs used, and the efficiency of energy use during the production process $[16,17]$, such as pruned biomass harvesting. Moreover, it helps in the management of the processes, as well as in decision-making based on the economy of energy resources, influencing the economic and environmental results [18], such as saving fossil fuels resources and emission reduction of greenhouse gases [19]. Concerning sustainable development in agriculture, Poland with the largest apple orchard area in Europe [20] could play an important role in supporting the delivery of waste biomass to the energy market.

Unfortunately, in the case of pruning harvesting for energy purposes, additional fuel and dedicated machinery use are required. To the group of the harvesting machineries belong various models of chippers and balers, whose task is to pick-up the cut branches and convert them to the expected form (wood chips or bales) [21]. However, the effectiveness of the harvesting machinery operation is limited due to technological restrictions, variable orchard characteristics, and the need to protect trees from damage of the machinery while passing. As a result, there are many parameters influencing the pruned biomass yield and harvesting losses and, thus, the energy balance.

One of the parameters influencing the pruned biomass yield is the pruning technique (manual, mechanized). Higher biomass yields were achieved in case of manual pruning of vineyards [22]. In turn, Acampora et al. [23] investigated the influence of the settings of the pick-up system of the machinery on the biomass properties and productivity. The authors revealed that a higher distance of the pick-up unit from the ground resulted in higher harvesting losses. Another issue is the problem of the topography of the permanent crop, which may also influence the biomass yield, especially in mountainous regions (higher slopes of the terrain). Research in vineyards performed by Spinelli et al. [24] indicated an increase of harvesting losses in the case of greater slopes. Similar observations were formulated by Nati et al. [25].

García-Galindo et al. [26] pointed out that, although the built-in windrowers in the machinery facilitate branches conveying toward the harvesters' inlet, the previous pre-alignment of pruned biomass in the inter-rows is more effective in reduction of losses and in the increase of speed during harvesting. Similar conclusions were formulated by Velázquez-Martí et al. [27], who investigated the influence of various management strategies (pruning options, concentration methods 
of pruned biomass, harvesting technologies) on the performance of the selected systems. Generally, a concentration of the pruned materials before chipping or baling contributed to better results, as the machines operated in a fixed position. Pari et al. [28] also indicated that the reduction of harvesting losses by a new harvester-chipper was probably a consequence of the interaction of the machine design and the efficiency of the pick-up system, which consists of a toothed roller with adjustable height from the control panel of the tractor. Dyjakon et al. [29] revealed that the use of windrowers in an apple orchard led to a significant reduction of harvesting losses (from $40 \%$ to $20 \%$ on average). Moreover, the energy balance was improved, although more energy input was required during the operation of the baler with windrowers [30]. In turn, in the report elaborated within the Europruning project [31], attention was paid to the importance of good practices and proper management in the orchard to proceed the production in a sustainable way with energetic benefits.

However, no direct comparisons of biomass harvesting yields and energy balances in apple orchards oriented toward the use of pruning residues for energy purposes (pruning to energy strategy (PtE)) were found. These data seem to be very important not only from a scientific point of view, but also from a practical point of view, as they create a possibility to have a better insight into the energetic, environmental, and economic aspects of orchards management in terms of pruned biomass.

Considering the benefits of energy analysis in production systems and its role for producers in decision-making, this study aimed to determine the energy demand and the energy output of two different strategies of pruning management in an apple orchard during biomass harvesting with the use of baling technology, i.e., (i) the owner pruned the branches and left them scattered in the orchard, and (ii) the owner pruned the branches and scraped them in the middle of the inter-rows for further treatment. Additionally, the costs of biomass harvesting, and the process efficiency based on various performance indicators were analyzed.

\section{Materials and Methods}

\subsection{Study Site, Experimental Design, and Data Collection}

The tests were carried out in an apple orchard located in Piaseczno (Warka community, Mazowieckie Province, Poland). The orchard was 10 years old. The apple variety was Idared (rootstock M9). The apple trees were irrigated, and the tree spacing was $3.4 \mathrm{~m} \times 1.0 \mathrm{~m}$ (2940 trees per hectare). The field was flat and covered by grass. The total area of cultivated apple orchard by the owner was 10 ha. The tree pruning was performed in the months of January-February, whereas the harvesting activities of the pruned biomass took place in April 2018. To harvest the biomass residues, a modified baler machine SIMPA Z279/1 Classic (Simpa S.A., Lublin, Poland) was applied (Figure 2). The baling machine was equipped only with a pick-up system and a rolling-pressing chamber. The available collection width for pruned residues harvested by the baler was limited to $1.8 \mathrm{~m}$. The baler was designed to produce bales with a diameter of $1.2 \mathrm{~m}$ and a height of $1.2 \mathrm{~m}$. The baler machine was powered through power take-off (PTO) by a John Deere 5075 GV tractor (Deere \& Company, Moline, IL, USA) with a power of $57 \mathrm{~kW}$.
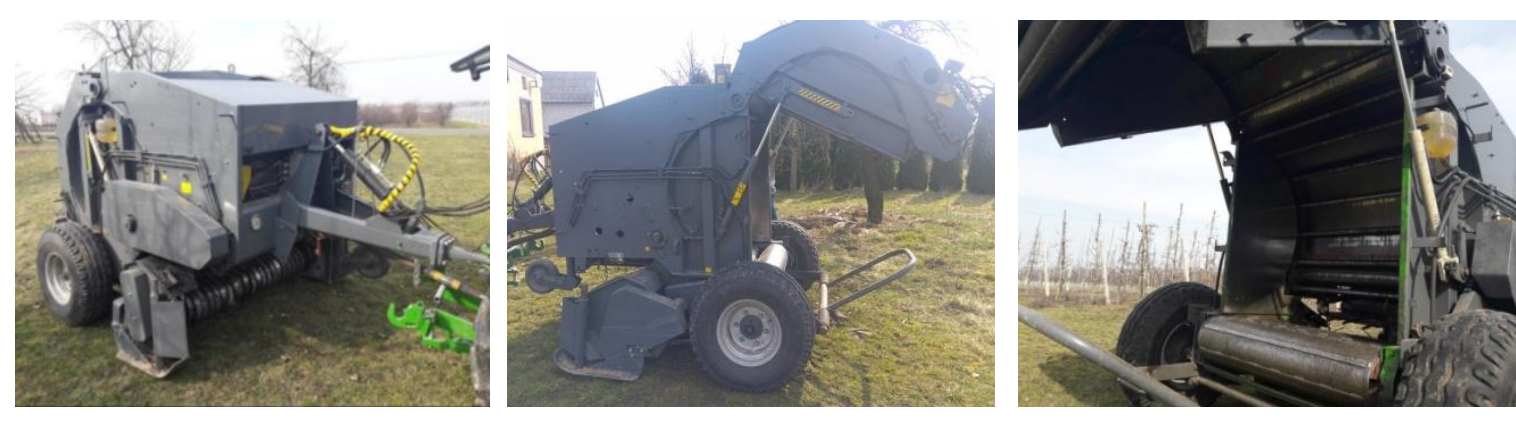

Figure 2. Baler machine SIMPA Z279/1 Classic. 
The tests were carried out in the apple orchard for two different pruning management strategies (Figure 3). In the first variant, the biomass harvesting took place in a part of the orchard where the apple trees were pruned, and the cut branches were left where they fell on the ground. In the second variant, the pruned biomass was windrowed in the inter-row corridor prior to further activities. The biomass residue harvesting step was applied, which removed the branches, creating the opportunity for their use for energy purposes.

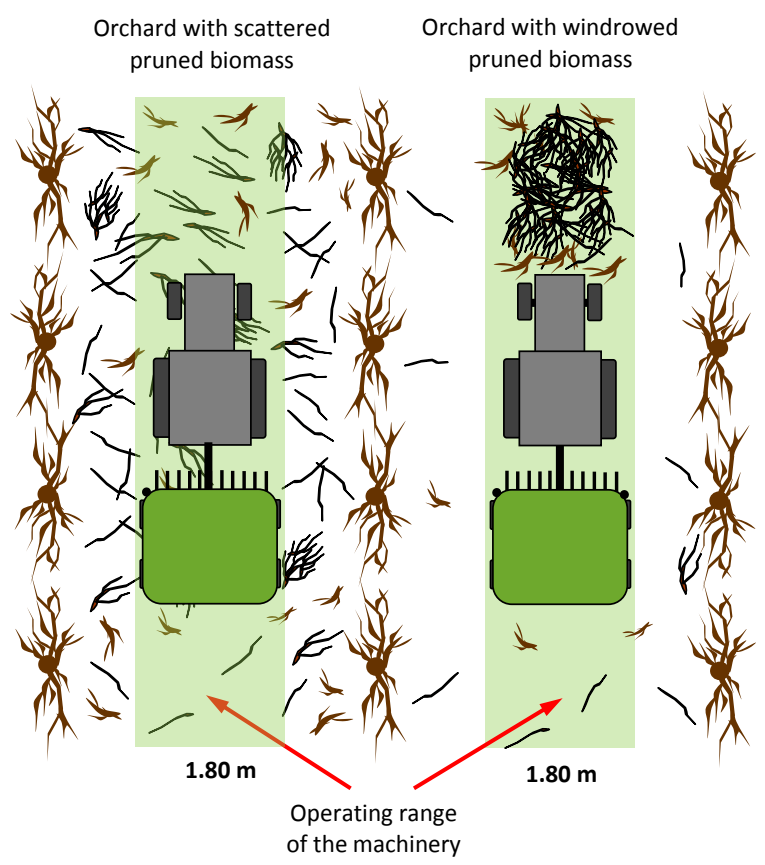

Figure 3. Investigated management variants with pruning biomass in the apple orchard.

\subsection{Biomass Properties and Productivity}

To perform laboratory analyses, 12 samples of about $1500 \mathrm{~g}$ of each pruning residue was collected in sealed bags. The samples came from both the produced bales (six samples) and the remaining biomass on the ground within the reference plots (six samples). In accordance with International Organization for Standardization (ISO) Standards, the moisture content [32], ash content [33], and higher heating value [34] were determined. To obtain the bale density, the weight of each bale was divided by its volume.

The pruning biomass yield (PB) was calculated as a total sum of the bale mass $(\mathrm{kg})$ collected during the tests from the field divided by the investigated area (ha). To measure the mass of the bale, an industrial scale Ditta-Seria DS. $1.5 \times 1.5 /$ P (Ditta-Seria, Nowe Miasto, Poland) with an accuracy of $\pm 1 \mathrm{~kg}$ was used. The harvested area of the orchard to generate bales was measured by a digital laser measure Bosch Professional GLM 50C (Bosch GmbH, Stuttgart, Germany). Harvesting losses due to the machine and process imperfections were determined by weighing the pruned biomass left on the field. For this purpose, six replicated plots with an average area of $70 \mathrm{~m}^{2}(3.5 \mathrm{~m} \times 20 \mathrm{~m})$ were randomly selected on the field for each variant. Each plot was selected from an area of not less than $1000 \mathrm{~m}^{2}$. Next, all pruning residues located inside the plot were manually collected and weighed with a digital gauge Lutron FG-5100 (Lutron Electronic Enterprise Co., Taipei, Taiwan), with an accuracy of $\pm 50 \mathrm{~g}$. Finally, the theoretical pruning potential was determined as the sum of pruning biomass yield and harvesting losses.

In both variants, the fuel consumption was measured by starting the test with a full tank and refilling the tank at the end of each cycle [11]. The change in weight of the canister with diesel was a measure of the level of fuel consumed during the test. 


\subsection{Economic Parameters and Working Time}

Data collection for both variants consisted of cost estimation and a set of detailed time and motion records conducted at a cycle level, in accordance with References [25,35]. Regarding the boundary conditions (Figure 4), as a full cycle, the production of a single bale was considered.

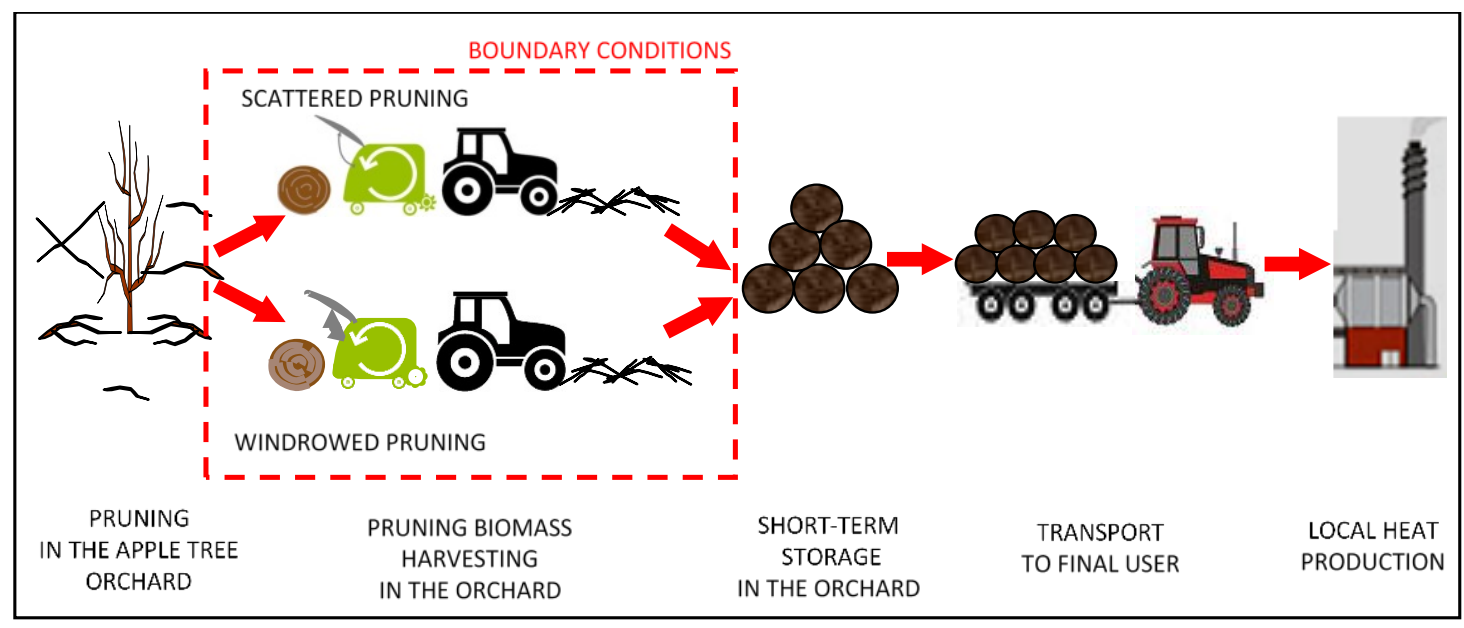

Figure 4. Boundary conditions for the economic and energy analysis in this study (pruning to energy (PtE) scheme).

The boundaries of this study excluded obligatory pruning costs (tree cutting), as this activity must be done regardless of the final treatment strategy of the biomass residues by the orchard's owner. Similarly, if the farmer wants to get rid of most of pruning from the orchard applying a mulching procedure, the cut branches must be placed in the middle of the inter-row corridor (windrowed). Therefore, in the PtE strategy, these costs are not taken into account either.

The cost estimation of the harvesting process in the apple orchard was performed according to the methodology proposed by Dyjakon [36] with the main data shown in Table 2. Concerning the harvesting activity, ownership costs were based on data provided by the orchard's owner (purchasing cost, service life, machinery usage), while operating costs were estimated using the data directly obtained during the field research, such as fuel consumption $\left(\mathrm{dm}^{3}\right.$ per scheduled machine hours $(\mathrm{SMH})$, field capacity $\left(\mathrm{SMH} \cdot \mathrm{ha}^{-1}\right)$, and pruning biomass yield $\left(\mathrm{Mg}\right.$ fresh mass $\left.(\mathrm{FM}) \cdot \mathrm{ha}^{-1}\right)$.

Table 2. Pruning harvesting cost data.

\begin{tabular}{cccc}
\hline Parameter & Unit & $\begin{array}{c}\text { Tractor } \\
\text { John Deere 5075 GV }\end{array}$ & $\begin{array}{c}\text { Baler } \\
\text { SIMPA Z279/1 Classic }\end{array}$ \\
\hline Power & $\mathrm{kW}$ & 54.0 & - \\
Investment & $€$ & 37,000 & 15,000 \\
Service life & $\mathrm{yr}$ & 15 & 10 \\
Trial work & $\mathrm{SMH} \cdot \mathrm{yr}^{-1}$ & 1500 & 500 \\
Resale & $\%$ & 20 & 28 \\
Interest rate & $\%$ & 7 & 2 \\
Inflation rate & $\%$ & 2 & 1 \\
Labor cost & $\%$ & 1 & - \\
Fuel cost & $€ \cdot \mathrm{h}^{-1}$ & 19 & - \\
Lubricant cost & $€ \cdot \mathrm{dm}^{-3}$ & 1.3 & 5 \\
Rexes, insurance, and housing & $€ \cdot \mathrm{dm}^{-3}$ & 5 & 50 \\
\hline
\end{tabular}

SMH—scheduled machine hours (the operation time of the machinery (including delays)); ${ }^{*}$ in accordance with Reference [11]. 
A labor cost of $€ 19.0 \mathrm{~h}^{-1}$ was assumed as an average value in the agricultural sector in the European Union (EU), although the cumulative labor cost of agriculture in Poland is ca. $€ 6.0 \mathrm{~h}^{-1}$. This very conservative approach was applied to display a safe margin of the total costs on the farmer's side, as well as to allow a more realistic comparison of the results against the background of the European bioenergy market.

The performance was evaluated by time records including the main indicators of operating times, such as total operating time (TO), effective operative time (TE), accessory time (TA), and wrapping time (TW). All time elements were recorded with a stopwatch. Total operating time was calculated as a sum of TE, TA, and TW. Effective operative time was related strictly to the harvesting step (pick-up of the branches and pressing in the chamber while driving in between the tree rows). Accessory time included the time for turning, as well as all necessary maintenances and stops (i.e., breaks in operation caused by the blocking of the baler machine feeding system by the cut branches). The wrapping time covered the temporary stopping of the machine to wrap the bale with a rope and discharge it outside. The records excluded all activities that were not directly related to the real operating conditions in the orchard (i.e., frequent refueling of the tank).

\subsection{Energy Factors}

The energy balance is an important tool to determine the efficiency of use of an agricultural system, quantifying input and output flows [37]. The energy flows and other related factors used during the analysis are presented in Table 3. The use of machinery in orchards with a total area of 400 ha was assumed for the calculation of energy indicators.

Table 3. Energy factors used in the analysis $[16,30,36]$.

\begin{tabular}{|c|c|c|c|}
\hline Factor & Symbol & Equation & Unit \\
\hline Direct energy input & $\mathrm{DE}$ & $\mathrm{DE}_{\mathrm{F}, \mathrm{L}}=\mathrm{M}_{\mathrm{F}, \mathrm{L}} \times \mathrm{E}_{\mathrm{F}, \mathrm{L}}$ & MJ.ha ${ }^{-1}$ \\
\hline Indirect energy input & IDE & $\mathrm{IDE}=\left(\frac{\mathrm{M}_{\mathrm{M}} \times \mathrm{E}_{\mathrm{M}}}{\mathrm{t}_{\mathrm{SLM}} \times \mathrm{t}_{\mathrm{M}}}\right) \times \mathrm{t}_{\mathrm{OP}}$ & $\mathrm{MJ} \cdot \mathrm{ha}^{-1}$ \\
\hline Energy input flow & EIF & $\mathrm{EIF}=\mathrm{DE}+\mathrm{IDE}$ & $\mathrm{MJ} \cdot \mathrm{ha}^{-1}$ \\
\hline Energy output flow & EOF & $\mathrm{EOF}=\mathrm{PB}_{\mathrm{FM}} \times\left(\frac{100-\mathrm{MC}_{\mathrm{FM}}}{100}\right) \times \mathrm{LHV}$ & MJ $\cdot \mathrm{ha}^{-1}$ \\
\hline Energy balance & EB & $\mathrm{EB}=\mathrm{EOF}-\mathrm{EIF}$ & $\mathrm{MJ} \cdot \mathrm{ha}^{-1}$ \\
\hline Energy return on investment & EROI & $\mathrm{EROI}=\frac{\mathrm{EOF}}{\mathrm{FIF}}$ & - \\
\hline Energy input share & EIS & $\mathrm{EIS}=\frac{\mathrm{EIF}}{\mathrm{EOF}} \times 100 \%$ & $\%$ \\
\hline Energy productivity & $\mathrm{EP}$ & $\mathrm{EP}=\frac{\mathrm{PB}_{\mathrm{FM}}}{\mathrm{FIF}}$ & $\mathrm{kg} \mathrm{FM} \cdot \mathrm{MJ}^{-1}$ \\
\hline Energy intensity & EI & $\mathrm{EI}=\frac{\mathrm{EOF}}{\mathrm{EB}}$ & $\mathrm{MJ} \cdot \mathrm{kg}^{-1} \mathrm{FM}$ \\
\hline
\end{tabular}

$\mathrm{M}_{\mathrm{F}, \mathrm{L}}$ is the total fuel (F) or lubricant (L) consumption by the machinery during pruned biomass harvesting, $\mathrm{kg}$; $\mathrm{E}_{\mathrm{F}, \mathrm{L}}$ is its energetic value of fuel or lubricant (51.50 MJ $\mathrm{kg}^{-1}$ for diesel and $83.7 \mathrm{MJ} \cdot \mathrm{kg}^{-1}$ for lubricants), $\mathrm{MJ} \cdot \mathrm{kg}^{-1} ; \mathrm{M}_{\mathrm{M}}$ is the mass of machine, $\mathrm{kg}$; $\mathrm{E}_{\mathrm{M}}$ is the energy used for machine production, $\mathrm{MJ} \cdot \mathrm{kg}^{-1}$; $\mathrm{t}_{\mathrm{SLM}}$ is the total service life of the machine, $\mathrm{yr} ; \mathrm{t}_{\mathrm{M}}$ is the assumed yearly use of the machine in the orchard, $\mathrm{SMH} \cdot \mathrm{yr}^{-1} ; \mathrm{t}_{\mathrm{OP}}$ is the cumulated scheduled machine hours in the orchard to harvest the pruned biomass, $\mathrm{SMH} ; \mathrm{PB}_{\mathrm{FM}}$ is the pruning biomass yield (fresh mass (FM)), $\mathrm{t} \mathrm{FM \cdot ha}{ }^{-1} ; \mathrm{MC}_{\mathrm{FM}}$ is the moisture content in the fresh mass of harvested biomass, \%; LHV is the lower heating value of the pruned dry apple tree biomass, $\mathrm{MJ} \cdot \mathrm{kg}^{-1}$.

\section{Results}

\subsection{Harvested Biomass Analysis}

The harvested pruning residues were in the form of cylindrical bales with a diameter of $1.25 \pm 0.05 \mathrm{~m}$ and a height of $1.25 \pm 0.05 \mathrm{~m}$. The average weight of the bales was $262 \pm 4 \mathrm{~kg}$ having a moisture content of $40.88 \pm 1.66 \%$, whereas the bulk density was $167 \pm 7 \mathrm{~kg} F M \cdot \mathrm{m}^{-3}$. The higher heating value was $19.02 \pm 0.13 \mathrm{MJ} \cdot \mathrm{kg}^{-1}$ dry mass (DM) and the lower heating value was calculated as $17.71 \mathrm{MJ} \cdot \mathrm{kg}^{-1} \mathrm{DM}\left(9.48 \mathrm{MJ} \cdot \mathrm{kg}^{-1} \mathrm{FM}\right)$. The ash content was $1.43 \pm 0.11 \%(\mathrm{DM})$. 


\subsection{Pruning Harvesting Productivity and Operation Time}

The theoretical pruning potential in the investigated apple orchard (Figure 5) was slightly above $2.50 \mathrm{t} \mathrm{FM} \cdot \mathrm{ha}^{-1}$. The area requested to produce one bale in the apple orchard prepared for pruning harvesting (windrowed pruning) was $1298 \pm 108 \mathrm{~m}^{2}$, whereas, in the case of scattered pruning in the orchard, the area increased to $3179 \pm 41 \mathrm{~m}^{2}$. In other words, in the case of the scattered pruned biomass in the orchard, the PB was only $0.76 \mathrm{t} \mathrm{FM} \cdot \mathrm{ha}^{-1}\left(0.45 \mathrm{t} \mathrm{DM} \cdot \mathrm{ha}^{-1}\right)$, resulting in significant harvesting losses amounting to $69.3 \%$. In turn, in the orchard with windrowed pruned biomass, the $\mathrm{PB}$ was $2.04 \mathrm{t} \mathrm{FM} \cdot \mathrm{ha}^{-1}\left(1.20 \mathrm{t} \mathrm{DM} \cdot \mathrm{ha}^{-1}\right)$, and the harvesting losses were $19.1 \%$.

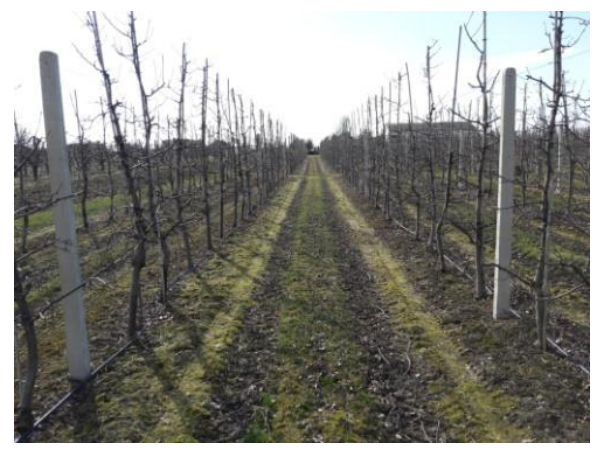

(a) apple orchard

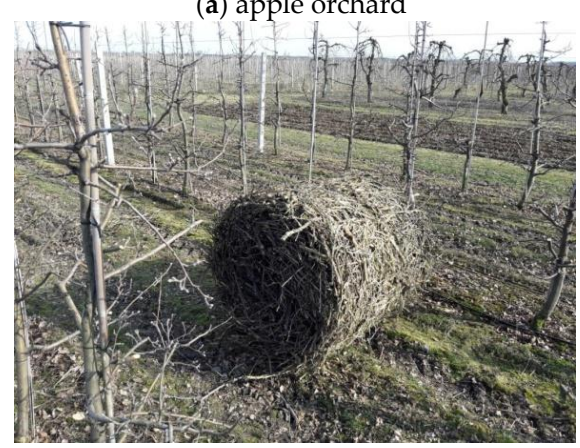

(c) pruned biomass bale

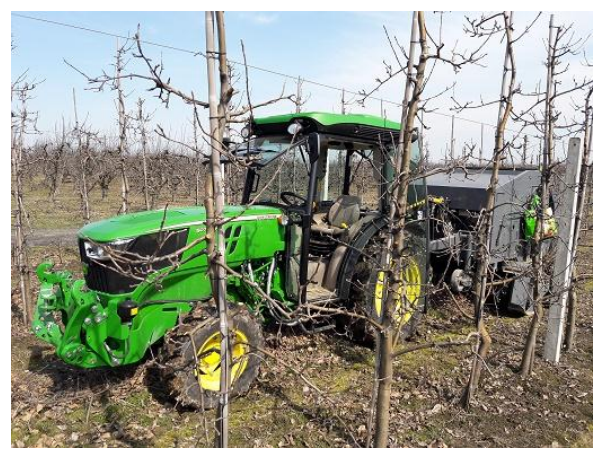

(b) tractor with a baler

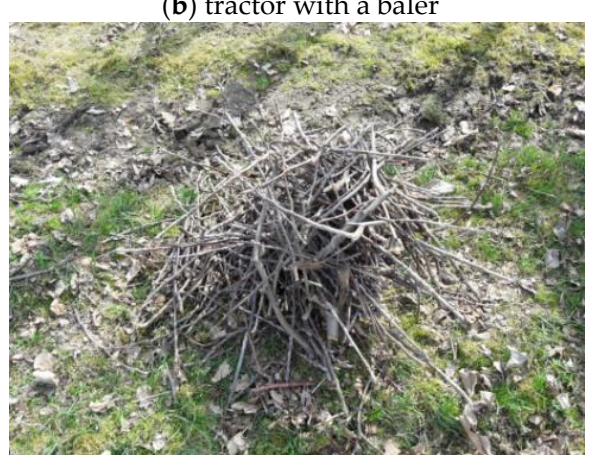

(d) harvesting losses

Figure 5. Harvesting of the pruned biomass in the apple orchard.

The pruning harvesting for energetic purposes is strongly influenced by the management strategy in the apple orchard. The productivity in the sections with scattered branches amounted to $0.54 \pm 0.11 \mathrm{Mg}$ FM.SMH ${ }^{-1}$. In contrast, if the branches were windrowed within the fruit tree corridors, this parameter reached a value of $1.16 \pm 0.19 \mathrm{Mg} \mathrm{FM} \cdot \mathrm{SMH}^{-1}$. The mean fuel consumption in the scattered and windrowed orchard was $5.32 \pm 0.61 \mathrm{dm}^{3} \cdot \mathrm{ha}^{-1}$ and $7.73 \pm 0.81 \mathrm{dm}^{3} \cdot \mathrm{ha}^{-1}$, respectively. The detailed results of the baler performance are shown in Table 4 .

In the considered variants (Figure 6), the highest manpower demanded TE (harvesting and baling) of $70.2 \%$ in the windrowed orchard and $79.0 \%$ in the scattered orchard. The TA covered $16.3 \%$ and $13.4 \%$ for the windrowed and scattered orchard, respectively. The least time was required for the wrapping process (for windrowed TW $=13.5 \%$; for scattered TW $=7.6 \%$ ). 
Table 4. Performance and fuel consumption of the pruning biomass baler.

\begin{tabular}{cccccc}
\hline \multirow{2}{*}{ Parameter } & Unit & \multicolumn{2}{c}{$\begin{array}{c}\text { Scattered Pruning } \\
\text { in the Orchard }\end{array}$} & \multicolumn{2}{c}{$\begin{array}{c}\text { Windrowed Pruning } \\
\text { in the Orchard }\end{array}$} \\
\cline { 3 - 6 } & & Mean & SD & Mean & SD \\
\hline Theoretical potential & $\mathrm{Mg} \mathrm{FM} \cdot \mathrm{ha}^{-1}$ & 2.53 & 0.30 & 2.54 & 0.26 \\
Pruning biomass yield & $\mathrm{Mg} \mathrm{FM} \cdot \mathrm{ha}^{-1}$ & 0.76 & 0.14 & 2.04 & 0.19 \\
Harvesting losses & $\%$ & 69.33 & 5.02 & 19.17 & 5.14 \\
Pruning capacity & $\mathrm{SMH} \cdot \mathrm{ha}^{-1}$ & 1.49 & 0.17 & 1.81 & 0.25 \\
Pruning productivity & $\mathrm{Mg} \mathrm{FM} \cdot \mathrm{SMH}^{-1}$ & 0.54 & 0.11 & 1.16 & 0.19 \\
& $\mathrm{Mg} \mathrm{DM} \cdot \mathrm{SMH}^{-1}$ & 0.32 & 0.06 & 0.68 & 0.10 \\
Fuel consumption & $\mathrm{dm}^{3} \cdot \mathrm{SMH}^{-1}$ & 3.65 & 0.31 & 4.32 & 0.59 \\
& $\mathrm{dm}^{3} \cdot \mathrm{ha}^{-1}$ & 5.32 & 0.61 & 7.73 & 0.81 \\
\hline
\end{tabular}

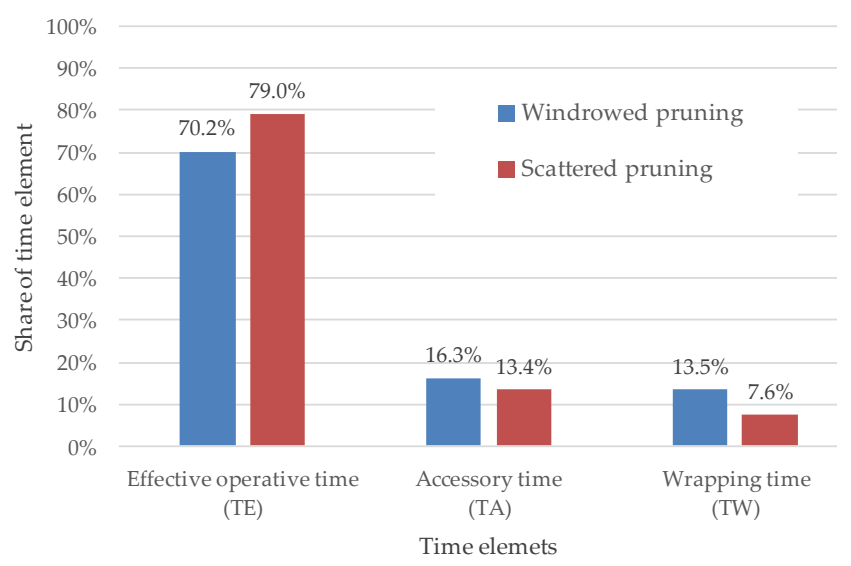

Figure 6. A share of time elements for harvesting activity in the apple orchard as a percentage of total operating time (TO).

\subsection{Economic Cost Analysis}

In the case of scattered pruning in the orchard, the harvesting and baling cost calculated for one hectare was $€ 60.26 \mathrm{ha}^{-1}$ (Table 5). For the windrowed orchard, this value amounted to $€ 75.42 \mathrm{ha}^{-1}$. In relation to the pruning biomass yield, the harvesting costs for the scattered and windrowed orchard were $€ 79.29 \mathrm{t}^{-1} \mathrm{FM}\left(€ 133.91 \mathrm{t}^{-1} \mathrm{DM}\right)$ and $€ 36.97 \mathrm{t}^{-1} \mathrm{FM}\left(€ 62.85 \mathrm{t}^{-1} \mathrm{DM}\right)$, respectively.

Table 5. Unit costs and potential profits for the evaluated pruned biomass harvesting variants in the apple orchard.

\begin{tabular}{cccc}
\hline Parameter & Unit & $\begin{array}{c}\text { Scattered Pruning } \\
\text { in the Orchard }\end{array}$ & $\begin{array}{c}\text { Windrowed Pruning } \\
\text { in the Orchard }\end{array}$ \\
\hline Harvesting and & $€ \cdot \mathrm{SMH}^{-1}$ & 40.51 & 41.63 \\
baling & $€ \cdot \mathrm{ha}^{-1}$ & 60.26 & 75.42 \\
& $€ \cdot \mathrm{t}^{-1} \mathrm{FM}$ & 79.29 & 36.97 \\
& $€ \cdot \mathrm{t}^{-1} \mathrm{DM}$ & 133.91 & 62.85 \\
\hline Bale (pruning) price & $€ \cdot \mathrm{t}^{-1} \mathrm{DM}$ & 90.0 & 90.0 \\
Income (bale selling) & $€ \cdot \mathrm{ha}^{-1}$ & 40.5 & 107.6 \\
Profit (net) & $€ \cdot \mathrm{ha}^{-1}$ & -19.8 & 32.1 \\
\hline
\end{tabular}

In turn, assuming the selling price of the bales (€90.0 $\left.\mathrm{t}^{-1} \mathrm{DM}\right)$, the net profit for the orchards with the scattered pruning was negative $\left(-€ 19.8 \mathrm{ha}^{-1}\right)$. In contrast, the net profit for the windrowed orchard was $€ 32.1 \mathrm{ha}^{-1}$. 


\subsection{Energetic Analysis}

The energetic data of the fuels and lubricants consumed throughout the duration of the study, as well as of the machineries employed including the mass, service life, and their operation time, are shown in Table 6.

Table 6. Energetic inputs and outputs for the evaluated pruned biomass harvesting variants in the apple orchard (the assumed operated orchard area was $400 \mathrm{ha}$ ).

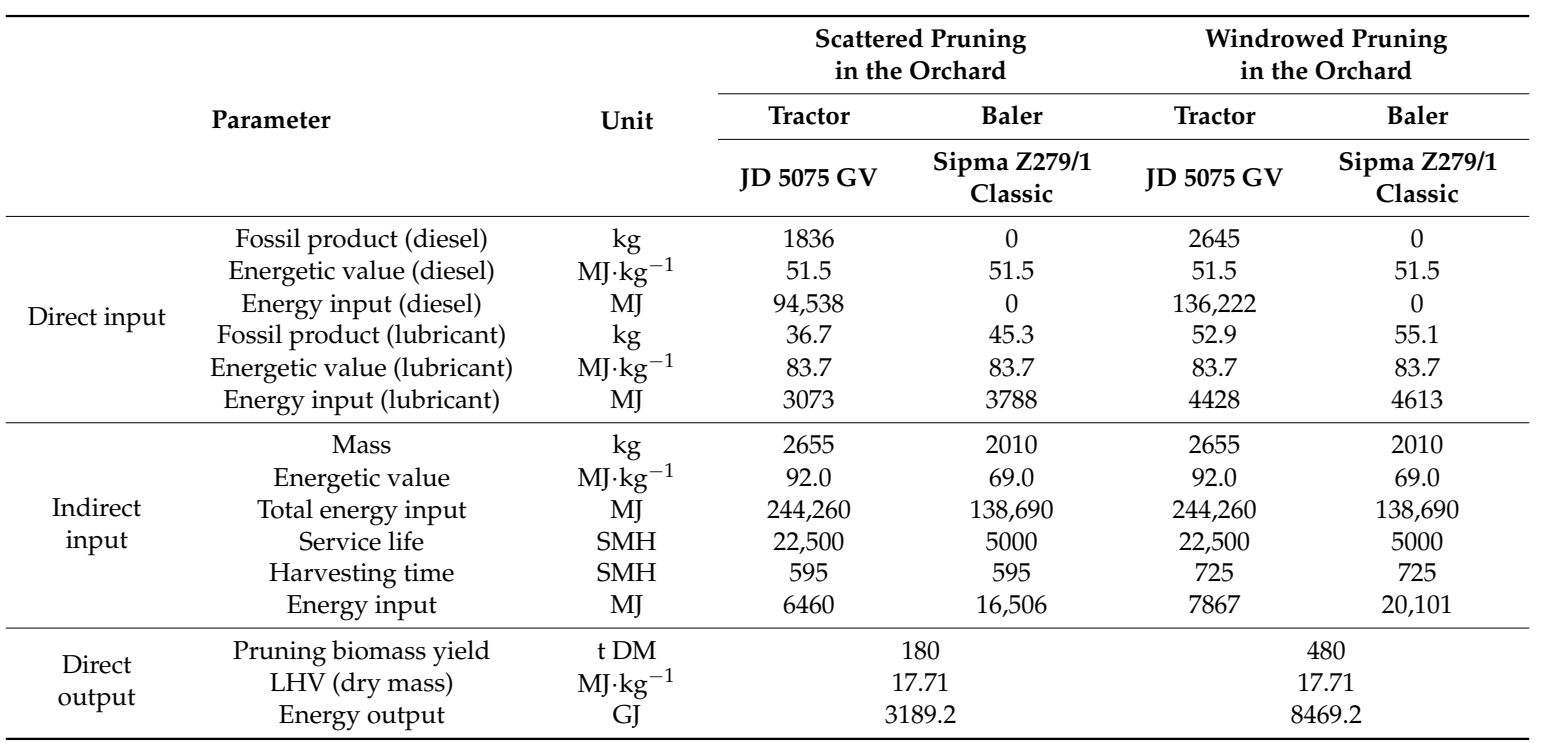

The cumulated energy input flow (EIF) was $310.9 \mathrm{MJ} \cdot \mathrm{ha}^{-1}$ for the scattered pruning and 433.1 MJ.ha ${ }^{-1}$ for the windrowed one (Table 7), whereas the energy output flow (EOF) factor for these two variants was almost $8.0 \mathrm{MJ} \cdot \mathrm{ha}^{-1}$ and $21.2 \mathrm{GJ} \cdot \mathrm{ha}^{-1}$, respectively. Based on the energy flows in the orchard, the energy indexes were calculated. The energy return on investment (EROI) index for the orchard with scattered pruning reached a value of ca. 25 , which was nearly half that of the properly windrowed orchard $($ EROI $=49)$.

Table 7. Energy flows and indexes for evaluated pruned biomass harvesting variants in the apple orchards.

\begin{tabular}{ccccc}
\hline Factor & & Unit & $\begin{array}{c}\text { Scattered Pruning } \\
\text { in the Orchard }\end{array}$ & $\begin{array}{c}\text { Windrowed Pruning } \\
\text { in the Orchard }\end{array}$ \\
\hline Direct energy input & DE & $\mathrm{MJ} \cdot \mathrm{ha}^{-1}$ & 253.5 & 363.2 \\
Indirect energy input & $\mathrm{IDE}$ & $\mathrm{MJ} \cdot \mathrm{ha}^{-1}$ & 57.4 & 69.9 \\
Energy input flow & $\mathrm{EIF}$ & $\mathrm{MJ} \cdot \mathrm{ha}^{-1}$ & 310.9 & 433.1 \\
Energy output flow & $\mathrm{EOF}$ & $\mathrm{MJ} \cdot \mathrm{ha}^{-1}$ & 7973 & 21,173 \\
Energy balance & $\mathrm{EB}$ & $\mathrm{MJ} \cdot \mathrm{ha}^{-1}$ & 7662 & 20,740 \\
Energy return on investment & EROI & - & 25.64 & 48.89 \\
Energy input share & EIS & $\%$ & 3.90 & 2.05 \\
Energy productivity & $\mathrm{FP}$ & $\mathrm{kg} \mathrm{FM} \cdot \mathrm{MJ}^{-1}$ & 2.45 & 4.72 \\
& & $\mathrm{~kg} \mathrm{DM} \cdot \mathrm{MJ}^{-1}$ & 1.45 & 2.76 \\
Energy intensity & $\mathrm{MJ} \cdot \mathrm{t}^{-1} \mathrm{FM}$ & 408.4 & 212.0 \\
& & $\mathrm{MJ} \cdot \mathrm{t}^{-1} \mathrm{DM}$ & 690.8 & 362.3 \\
\hline
\end{tabular}

From an energetic point of view, the determined energy input share (EIS) values were very positive and accounted for less than $4 \%$ for both variants. Moreover, energy productivity $(\mathrm{EP})=1.45 \mathrm{~kg} \mathrm{DM} \cdot \mathrm{MJ}^{-1}$ and energy intensity $(\mathrm{EI})=690.8 \mathrm{MJ} \cdot \mathrm{t}^{-1} \mathrm{DM}$ during the biomass harvesting in the apple orchard with scattered pruning were obtained. However, the proper management of 
the orchard thanks to the windrowing of the pruning caused a significant improvement in these parameters, i.e., $\mathrm{EP}=2.76 \mathrm{~kg} \mathrm{DM} \cdot \mathrm{MJ}^{-1}$ and $\mathrm{EI}=362.3 \mathrm{MJ} \cdot \mathrm{t}^{-1} \mathrm{DM}$.

\section{Discussion}

The theoretical pruning potential in the investigated apple orchard was $2.5 \mathrm{t} \mathrm{FM} \cdot \mathrm{ha}^{-1}$. This value is below the average potential amount of $3.5 \mathrm{t} \mathrm{FM} \cdot \mathrm{ha}^{-1}$ determined for this kind of permanent crop in Poland [38]. However, the potential might still be sufficient if proper management is engaged. In this study, when the harvesting activity took place in the orchard with scattered pruning, PB was very low $\left(0.76 \mathrm{t} \mathrm{FM} \cdot \mathrm{ha}^{-1}\right)$ with high harvesting losses reaching ca. $70 \%$. This resulted from a large distance between the trees rows, which, in apple orchards, is usually not less than $3.2 \mathrm{~m}$, in comparison to the working width of the round baler $(1.8 \mathrm{~m})$. As a result, the branches lying closer to the tree trunks could not be collected. Although it is possible to pass the rows twice with the machine to cover the entire available area in the inter-rows, such a solution is not practiced, because the height of the baler is ca. 2.0, and its housing elements can damage trees and cause losses in fruit production while driving next to the trees.

In the case of the windrowed pruning, the PB increased to $2.0 \mathrm{t} \mathrm{FM} \cdot \mathrm{ha}^{-1}$ with the harvesting losses below $20 \%$. The obtained value is satisfactory, and the coefficient of harvesting losses is close to that reported by Dyjakon et al. [29], who revealed that the use of windrowers mounted to the baler caused a decrease in harvesting losses in apple orchards from $40 \%$ to $20 \%$. Therefore, to increase the biomass yield, the farmer should focus firstly on the concentration of the biomass residues in the middle of the inter-row corridor. It should be marked, however, that the concentration of pruned biomass is a common practice in the case of the mulching process to get rid of most of the cut branches and leave the chipped material in the apple orchard. As this mandatory procedure is currently the most popular across the apple orchards [14], the energy input and costs related to this activity (pruning concentration) were not taken into account.

The PB increase affects both the energy output and the energy input. The consequence of higher productivity in the windrowed orchard is an increased fuel consumption $\left(7.73 \mathrm{dm}^{3} \cdot \mathrm{ha}^{-1}\right.$ versus $5.32 \mathrm{dm}^{3} \cdot \mathrm{ha}^{-1}$ for the orchard with scattered pruning) and pruning capacity $\left(1.81 \mathrm{SMH} \cdot \mathrm{ha}^{-1}\right.$ versus $1.49 \mathrm{SMH} \cdot \mathrm{ha}^{-1}$ for the orchard with scattered pruning). More biomass collected from one hectare required more time spent to harvest, wrap, and unload the bales. Similar correlations were observed by Velazquez-Marti et al. [27] during pruning, harvesting, and chipping.

Concerning the TO parameter in detail, the performed calculations revealed that the TE parameter in both cases represented the greatest share of TO, which is in line with the results obtained by other researchers during the pruning harvesting activities in different permanent crops [11,39]. A higher TE value for the orchard with scattered pruning resulted from a lower PB and fewer problems with the collection of cut branches. This correlation was confirmed by higher values of TA (including also delays) and TW (Figure 6). In the case of windrowed pruning in the orchard, more bales were generated. Therefore, more time was spent to wrap the bales (13.5\% versus $7.6 \%)$, as well as to overcome some technical difficulties occurring during machinery operation (16.3\% versus $13.4 \%$ ).

A larger number of pruned branches also forces a better matching of the passing speed in the orchard [40] to maintain efficient harvesting and prevent unexpected stops and delays. The speed of the tractor should not exceed the speed of the pick-up and the feeding system of the baler. A lower velocity reduces the probability and the risk of blockage/clogging of the feed shaft chamber. PB also influenced the power demand. At a higher load of the baler, more energy is transferred from the tractor by PTO (the difference in fuel consumption in Table 4). However, while relating the average unit fuel consumption to the production of one bale in the orchard, the indexes are much more favorable for greater PB values. The fuel consumption in the orchard with scraped branches was $1.00 \mathrm{dm}^{3} \cdot \mathrm{bale}^{-1}$, which was much lower than that in the orchard with scattered pruning $\left(1.69 \mathrm{dm}^{3} \cdot \mathrm{bale}^{-1}\right)$. The results of the research performed by Mathanker and Hansen [41] also revealed that, although fuel consumption 
was directly correlated to miscanthus yield, the ratio between fuel consumption and unit mass of the harvested material was positive.

The pruning capacity significantly influenced the costs of the harvesting and baling process in the apple orchard. In relation to the orchard area of one hectare, the costs of a cumulative working hour in the orchard with windrowed pruning $\left(€ 75.42 \mathrm{ha}^{-1}\right)$ were ca. $€ 15$ higher than those in the orchard with scattered pruning $\left(€ 60.26 \mathrm{ha}^{-1}\right)$. However, referring the operation costs to one ton of harvested biomass, the costs for an orchard with windrowed pruning amounted to $€ 36.97 \mathrm{t}^{-1} \mathrm{FM}$, ca. $€ 40$ cheaper than for the orchard with scattered pruning ( $\left.€ 79.42 \mathrm{t}^{-1} \mathrm{FM}\right)$. This indicates that PB is essential for harvesting costs and final economic indicators. Furthermore, an increase in PB reduces unit harvesting costs [42]. For the considered management variants, the harvesting costs in the orchard with scattered pruning (very low $\mathrm{PB}$ ) exceeded the potential profits from the pruned bale selling. Therefore, the balance of the harvesting costs and the selling price was $-€ 19.8 \mathrm{ha}^{-1}$. Thus, improper management or low biomass potential can make the harvesting process economically unjustified. However, it should be noted that the costs of mulching one hectare would generate an even worse balance, as the unit cost of mulching is in the range of $€ 35-50 \mathrm{SMH}^{-1}[25,36]$. Assuming the operation time of a tractor with a mulcher in the orchard $\left(1.49 \mathrm{SMH} \cdot \mathrm{ha}^{-1}\right.$ for the harvester in this study, lowered by $30 \%$ for the mulching process time) and the unit cost of mulching in the amount of $€ 40 \mathrm{SMH}^{-1}$, the total mulching process cost can be estimated at $€ 41.7 \mathrm{ha}^{-1}$. As the mulching process does not provide any direct income, its economic balance is $-€ 41.7 \mathrm{ha}^{-1}$. Thus, it is better to collect the pruning than to mulch it. Furthermore, if the costs of mulching in the orchard are assigned as avoided costs, the final balance could be determined as positive (ca. $€ 22 \mathrm{ha}^{-1}$ ).

In the case of the windrowed pruning in the orchard, the financial balance was positive $\left(€ 32.1 \mathrm{ha}^{-1}\right)$ regardless of the mulching costs. By additionally including the avoided costs of mulching, the profits rose to $€ 83 \mathrm{ha}^{-1}$. From a practical point of view and management strategy of the orchard, knowledge of the minimum PB is important, which ensures reimbursement of expenses (without consideration of the avoided costs of mulching). Using the obtained data, it can be concluded that positive economic results may be achieved at the minimal $\mathrm{PB}=0.68 \mathrm{tDM} \cdot \mathrm{ha}^{-1}$.

However, these values also depend on the labor costs, which vary across the EU countries. As shown in Figure 7, for windrowed pruning in the orchard, a decrease in labor costs led to higher benefits for the owner. This resulted mainly from the high PB value achieved thanks to the effective harvesting procedure. It is important to note that, despite higher labor costs, the economic balance was beneficial. Unfortunately, if the orchard is not properly managed (scattered pruning), even a significant reduction in labor costs is not able to generate acceptable profits. The economic balance is only positive for labor costs in the range of $€ 6-7 \mathrm{~h}^{-1}$ (if the avoided costs of mulching are excluded). The main reason seems to be a small value of the PB parameter, resulting in low income from the sale of biomass residues.

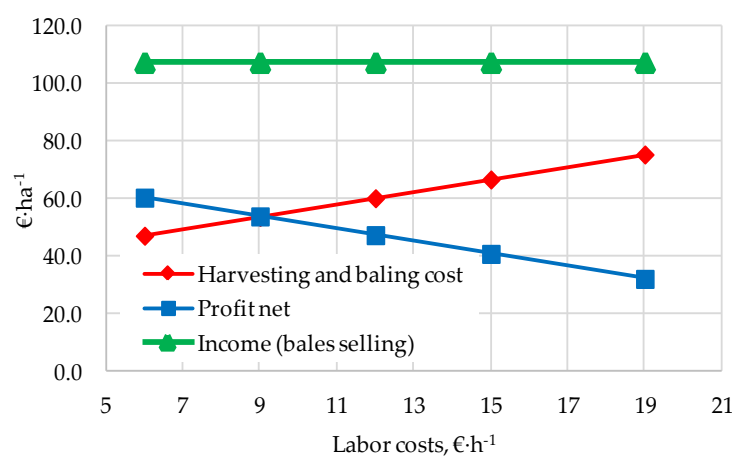

(a) windrowed pruning in the orchard

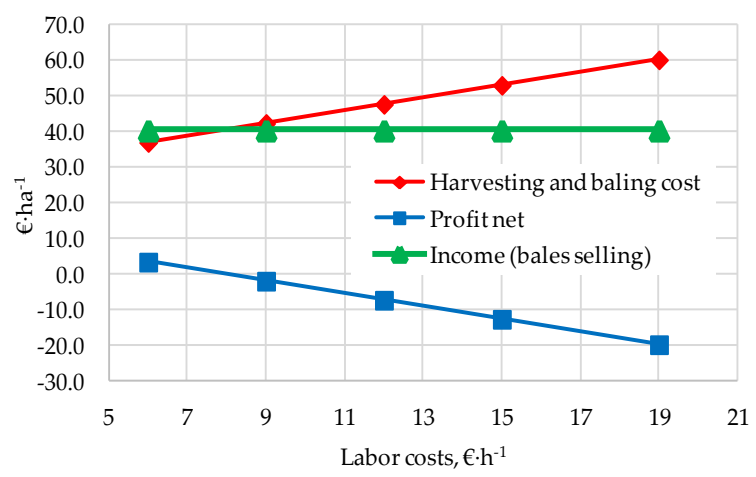

(b) scattered pruning in the orchard

Figure 7. Influence of labor costs on economic benefits in the orchard. 
The results must be treated with care, as the calculations are limited to the costs at the orchard gate, and the transportation/delivery costs to the final user are excluded from this analysis.

In the context of energy flow, both variants characterize positive results. However, there are significant differences in EOF and finally in energy balance (EB). For the windrowed pruning in the orchard, EB $\left(20.74 \mathrm{GJ} \cdot \mathrm{ha}^{-1}\right)$ was almost three times larger than for the scattered pruning in the orchard $\left(7.66 \mathrm{GJ} \cdot \mathrm{ha}^{-1}\right)$. Such a disproportion was caused mainly by high harvesting losses $(69.33 \%)$ for scattered branches, reflected in the biomass yield accounting for only $0.76 \mathrm{Mg} \cdot \mathrm{ha}^{-1}$ and a low EOF of $7.97 \mathrm{GJ} \cdot \mathrm{ha}^{-1}$. In turn, for the windrowed pruning in the orchard, the harvesting losses were remarkably lower (19.17\%), transforming into a high EOF of $21.17 \mathrm{GJ} \cdot \mathrm{ha}^{-1}$. In order to emphasize the importance and energy efficiency of the pruned biomass acquisition from the orchard for energy purposes, the indicator EIS was specified, as well. For the scattered orchard, EIS $=3.90 \%$, and it was roughly twice as large as that for the windrowed orchard (EIS $=2.05 \%$ ). Consequently, if more energy input is required in the orchards with windrowed pruning and EIS is still lower, then it might be concluded that PB is the most important index influencing the energy performance. It proves that management of the orchard should focus on the creation of operation conditions facilitating the harvesting process and, thus, increasing EB.

Another issue is the assessment of the competitiveness of the two variants used alternatively to harvest the biomass residues in the orchards for energy purposes, namely pruned biomass baling and pruned biomass chipping. In the considered cases, EIFs amounted to $0.31 \mathrm{GJ} \cdot \mathrm{ha}^{-1}$ (the scattered pruning) and $0.43 \mathrm{GJ} \cdot \mathrm{ha}^{-1}$ (the windrowed pruning). These values are in line with the estimated EIF parameters during the pruning baling performed in other apple orchards, where EIF was in the range of $0.33-0.50 \mathrm{GJ} \cdot \mathrm{ha}^{-1}[30,36]$. On the other hand, analyzing EB in an apple orchard where the chipping technology was applied [25], EIF related to the harvesting and chipping only was $0.86 \mathrm{GJ} \cdot \mathrm{ha}^{-1}$. Thus, from a strictly energetic point of view, the baling process in the orchard is less energy intensive. The EB for the scattered pruning in the orchard $\left(7.66 \mathrm{GJ} \cdot \mathrm{ha}^{-1}\right)$ is even better for the baling technology than for the chipping (5.44 GJ.ha $\left.{ }^{-1}\right)$ [25].

However, the positive results arising from lower costs and higher EB on the baling technology side may turn out to be useless if there is no demand for such form of fuel (round bales) on the local energy market. The transportation of biomass and logistics issues should also be taken into account [43]. In this context, a proper market analysis must be carried out in order to ensure the continuity of the logistics process and the implementation of the PtE strategy [36].

\section{Conclusions}

The performed analysis and applied energy indexes revealed that the management strategy in the orchard has great importance in terms of energetic and economic consequences. The analysis concerned a specific orchard. The collection of pruning in a scattered orchard resulted in a very low productivity, low biomass yield, and high harvesting losses. In the case of pruning being windrowed to the middle of the apple tree corridors, higher productivity, higher biomass yield, and low harvesting losses were obtained. In both variants, the energy balance was positive. However, a positive economic balance was achieved only for the windrowed orchard.

In comparison to the mulching process, the results showed that, regardless of the orchard preparation, pruning harvesting can at least reduce the costs of orchard cleaning. With proper management, the income from biomass sale can be significantly higher, leading to a lowering of the total apple production costs.

This study highlights that orchard management is a critical parameter affecting energy recovery, as well as financial returns.

Further work should address important topics, such as the principles of best selection of the harvesting procedure in terms of the pruning methods, the width of the inter-rows, and the equipment and the settings of the machinery. Finally, there are still unsolved issues related to the management 
strategy, including the correlations between machine productivity, settings, harvesting losses, and fuel quality.

Funding: This research received no external funding.

Acknowledgments: The author gives special thanks to the owners of the apple orchard, Tomasz and Filip Stomski, for participation and assistance in field research and providing the data necessary to perform this work.

Conflicts of Interest: The authors declare no conflicts of interest.

\section{Abbreviations}

\begin{tabular}{|c|c|}
\hline $\mathrm{DE}$ & direct energy \\
\hline $\mathrm{DM}$ & dry mass \\
\hline $\mathrm{EB}$ & energy balance \\
\hline EI & energy intensity \\
\hline EIF & energy input flow \\
\hline EIS & energy input share \\
\hline $\mathrm{EOF}$ & energy output flow \\
\hline $\mathrm{EP}$ & energy productivity \\
\hline EROI & energy return on investment \\
\hline FM & fresh mass \\
\hline HHV & higher heating value \\
\hline IDE & indirect energy \\
\hline LHV & lower heating value \\
\hline $\mathrm{MC}$ & moisture content \\
\hline O\&M & operation and maintenance \\
\hline $\mathrm{PtE}$ & pruning to energy \\
\hline PTO & power take-off \\
\hline $\mathrm{PB}$ & pruning biomass yield \\
\hline SD & standard deviation \\
\hline $\mathrm{SMH}$ & scheduled machine hours \\
\hline TA & accessory time \\
\hline $\mathrm{TE}$ & effective operative time \\
\hline $\mathrm{TO}$ & total operating time \\
\hline TW & wrapping time \\
\hline
\end{tabular}

\section{References}

1. European Commission. Directive 2009/28/EC of the European Parliament and of the Council-On the Promotion of the Use of Energy from Renewable Sources and Amending and Subsequently Repealing Directives 2001/77/EC and 2003/30/EC; European Commission: Brussels, Belgium, 2009.

2. European Commission. On Sustainability Requirements for the Use of Solid and Gaseous Biomass Sources in Electricity, Heating and Cooling-Report from the Commission to the Council and European Parliament; COM(2010)11; European Commission: Brussels, Belgium, 2010.

3. United Nations Environmental Programme (UNEP). Converting Waste Agricultural Biomass into a Resource. Compendium of Technologies; UNEP: Osaka/Shiga, Japan, 2009.

4. World Bioenergy Association. Global Biomass Potential Towards 2035; World Bioenergy Association: Stockholm, Sweden, 2016. Available online: https://worldbioenergy.org/uploads/Factsheet_Biomass\%20potential.pdf (accessed on 15 November 2018).

5. Baruya, P. World Forest and Agricultural Crop Residue Resources for Cofiring; IEA Clean Coal Centre: London, UK, 2015, ISBN 978-92-9029-571-6.

6. Daioglou, V.; Stehfest, E.; Wicke, B.; Faaij, A.; van Vuuren, D.P. Projections of the availability and cost of residues from agriculture and forestry. GCB Bioenergy 2016, 8, 456-470. [CrossRef]

7. European Commission. Innovating for Sustainable Growth-A Bioeconomy for Europe; Publications Office of the European Union: Luxembourg, 2012, ISBN 978-92-79-25376-8. 
8. European Commission. Communication from the Commission to the European Parliament, the Council, the European Economic and Social Committee and the Committee of the Regions; Closing the Loop-An EU Action Plan for the Circular Economy; European Commission: Brussels, Belgium, 2 December 2015.

9. United Nations Environmental Programme (UNEP). Technologies for Converting Waste Agricultural Biomass to Energy; UNEP: Osaka, Japan, 2013.

10. Castillo-Ruiz, F.J.; Sola-Guirado, R.R.; Castro-Garcia, S.; Gonzalez-Sanchez, E.J.; Colmenero-Martinez, J.T.; Blanco-Roldán, G.L. Pruning systems to adapt traditional olive orchards to new integral harvesters. Sci. Hortic. 2017, 220, 122-129. [CrossRef]

11. Toscano, G.; Alfano, V.; Scarfone, A.; Pari, L. Pelleting vineyard pruning at low cost with a mobile technology. Energies 2018, 11, 2477. [CrossRef]

12. Ekinci, K. Utilization of apple pruning residues as a source of biomass energy: A case study in Isparta province. Energy Explor. Exploit. 2011, 29, 87-107. [CrossRef]

13. Dyjakon, A.; Mudryk, K. Energetic Potential of Apple Orchards in Europe in Terms of Mechanized Harvesting of Pruning Residues. In Renewable Energy Sources: Engineering, Technology, Innovation; Springer Proceedings in Energy; Mudryk, K., Werle, S., Eds.; Springer: Cham, Switzerland, 2018; pp. 593-602.

14. Garcia-Galindo, D.; Gomez-Palmero, M.; Germer, S.; Pari, L.; Afano, V.; Dyjakon, A.; Sagarna, J.; Rivera, S.; Poutrin, C. Agricultural pruning as biomass resource: Generation, potentials and current fates. An approach to its state in Europe. In Proceedings of the 24th European Biomass Conference and Exhibition (EUBCE), Amsterdam, The Netherlands, 6-9 June 2016; pp. 1579-1595. [CrossRef]

15. Guzman Casado, G.I.; de Gonzalez Molina, M. Energy in Agroecosystems: A Tool for Assessing Sustainability, 1st ed.; CRC Press: Boca Raton, FL, USA, 2016.

16. Andrea, M.C.S.; Tieppo, R.C.; Gimenez, L.M.; Povh, F.P.; Katsman, T.J.; Romanelli, T.L. Energy demand in agricultural biomass production in Parana state, Brazil. Agric. Eng. Int. 2014, 2014, 42-51.

17. Nordborg, M.; Berndes, G.; Dimitriou, I.; Henriksson, A.; Mola-Yudego, B.; Rosenqvist, H. Energy analysis of willow production for bioenergy in Sweden. Renew. Sustain. Energy Rev. 2018, 93, 473-482. [CrossRef]

18. Pyörälä, P.; Kellomäki, S.; Peltola, H. Effects of management on biomass production in Norway spruce stands and carbon balance of bioenergy use. For. Ecol. Manag. 2012, 275, 87-97. [CrossRef]

19. Macedo, I.C. Greenhouse gas emissions and energy balances in bio-ethanol production and utilization in Brazil (1996). Biomass Bioenergy 1998, 14, 77-81. [CrossRef]

20. The Food and Agriculture Organization (FAO). 2017. Available online: http://www.fao.org/faostat/en/ \#data/QC (accessed on 25 December 2018).

21. Pari, L.; Suardi, A.; Frąckowak, P.; Adamczyk, F.; Szaroleta, M.; Santangelo, E.; Bergonzoli, S.; Del Giudice, A.; Dyjakon, A. Two innovative prototypes for collecting pruning biomass: Early performance tests and assessment of the work quality. Biomass Bioenergy 2018, 117, 96-101. [CrossRef]

22. Spinelli, R.; Nati, C.; Pari, L.; Mescalchin, E.; Magagnotti, N. Production and quality of biomass fuels from mechanized collection and processing of vineyard pruning residues. Appl. Energy 2012, 89, 374-379. [CrossRef]

23. Acampora, A.; Croce, S.; Assirelli, A.; Del Giudice, A.; Spinelli, R.; Suardi, A.; Pari, L. Product contamination and harvesting losses from mechanized recovery of olive tree pruning residues for energy use. Renew. Energy 2013, 53, 350-353. [CrossRef]

24. Spinelli, R.; Lombardini, C.; Pari, L.; Sadauskiene, L. An alternative to field burning of pruning residues in mountain vineyards. Ecol. Eng. 2014, 70, 212-216. [CrossRef]

25. Nati, C.; Boschiero, M.; Picchi, G.; Mastrolonardo, G.; Kelderer, M.; Zerbe, S. Energy performance of a new biomass harvester for recovery of orchard wood wastes as alternative to mulching. Renew. Energy 2018, 124, 121-128. [CrossRef]

26. García-Galindo, D.; Gómez-Palmero, M.; López, E.; Sebastián, F.; Jirjis, R.; Gebresenbet, G.; Germer, S.; Pari, L.; Suardi, A.; Lapeña, A.; et al. Agricultural pruning harvesting demonstrations in Germany, France and Spain. Lessons learned and recommendations. In Proceedings of the 24th European Biomass Conference and Exhibition (EUBCE), Amsterdam, The Netherlands, 6-9 June 2016; pp. 1727-1733. [CrossRef]

27. Velazquez-Marti, B.; Fernandez-Gonzales, E.; Callejon-Ferre, A.J.; Estornell-Cremades, J. Mechanized methods for harvesting residual biomass from Mediterranean fruit tree cultivations. Sci. Agric. 2012, 69, 180-188. [CrossRef] 
28. Pari, L.; Suardi, A.; Del Giudice, A.; Scarfone, A.; Santangelo, E. Influence of chipping system on chipper performance and wood chip particle size obtained from peach prunings. Biomass Bioenergy 2018, 112, 121-127. [CrossRef]

29. Dyjakon, A.; Adamczyk, F.; Szaroleta, M.; Pari, L.; Suardi, A.; Germer, S. Harvesting of agricultural wood residues from apple orchards using a pruning round baler. Wood 2019, 203. [CrossRef]

30. Dyjakon, A. The influence of the use of windrowers in baler machinery on the energy balance during pruned biomass harvesting in the apple orchard. Energies 2018, 11, 3236. [CrossRef]

31. EuroPruning. Best Practice Brochure for a Sustainable and Sound Utilization of Wood Prunings as Biomass Feedstock. Deliverable Report D8.4. 2016. Available online: www.europruning.eu (accessed on 14 September 2018).

32. ISO 18134-1:2015 Solid Biofuels. Determination of Moisture Content. Oven Dry Method-Part 1. Total Moisture. Reference Method. Available online: https:/ /www.iso.org/standard/61538.html (accessed on 6 April 2018).

33. ISO 18122:2015. Solid Biofuels. Determination of Ash Content. Available online: https://www.iso.org/ standard/61515.html (accessed on 6 April 2018).

34. ISO 18125:2017. Solid Biofuels. Determination of Calorific Value. Available online: https://www.iso.org/ standard/61517.html (accessed on 6 April 2018).

35. IUFRO. WP3.04.02. Forest Work Study Nomenclature, Test Edition Valid 1995-2000; Swedish University of Agricultural Sciences, Department of Operational Efficiency: Garpenberg, Sweden, 1995, ISBN 91-576-5055-1.

36. Dyjakon, A. Harvesting and baling of pruned biomass in apple orchards for energy production. Energies 2018, 11, 1680. [CrossRef]

37. Hetz, J.H. Energy utilization in Chilean agriculture. Agric. Mech. Asia Afr. Latin Am. 1992, 23, 52-56.

38. Dyjakon, A.; Den Boer, J.; Bukowski, P.; Adamczyk, F.; Frackowiak, P. Wooden biomass potential from apple orchards in Poland. Wood 2016, 59, 73-86.

39. Manzone, M.; Gioelli, F.; Balsari, P. Kiwi clear-cut: First evaluation of recovered biomass for energy production. Energies 2017, 10, 1837. [CrossRef]

40. Spinelli, R.; Magagnotti, N.; Nati, C.; Cantini, C.; Sani, G.; Picchi, G.; Biocca, M. Integrating olive grove maintenance and energy biomass recovery with a single-pass pruning and harvesting machine. Biomass Bioenergy 2011, 35, 808-813. [CrossRef]

41. Mathanker, S.K.; Hansen, A.C. Impact of miscanthus yield on harvesting cost and fuel consumption. Biomass Bioenergy 2015, 81, 162-166. [CrossRef]

42. Spinelli, R.; Picchi, G. Industrial harvesting of olive tree pruning residue for energy biomass. Bioresour. Technol. 2010, 101, 730-735. [CrossRef]

43. Bosona, T.; Gebresenbet, G.; Olsson, S.-O.; Garcia, D.; Germer, S. Evaluation of a smart system for the optimization of logistics performance of a pruning biomass value chain. Appl. Sci. 2018, 8, 1987. [CrossRef] 